\title{
Historical Evolution of Scientific Initiation Projects in the Area of Environmental Education
}

\author{
Márcia Aparecida Andreazzi ${ }^{1,2 *}$, Vinícius Eduardo Gargaro Silva ${ }^{1}$, Edneia Aparecida de Souza Paccola ${ }^{1}$, \\ Fábio Luiz bim Cavalieri ${ }^{1}$
}

${ }^{1}$ Centro Universitário de Maringá/ UNICESUMAR, BRAZIL

${ }^{2}$ ICETI - Cesumar Institute of Science, Technology and Innovatio, BRAZIL

*Corresponding Author: marcia.andreazzi@unicesumar.edu.br

Citation: Andreazzi, M. A., Silva, V. E. G., Paccola, E. A. d. S., \& Cavalieri, F. L. b. (2019). Historical Evolution of Scientific Initiation Projects in the Area of Environmental Education. Interdisciplinary Journal of Environmental and Science Education, $15(1)$, e02205. https://doi.org/10.29333/ijese/6290

\section{ARTICLE INFO}

Received: 4 Oct. 2019

Revised: 27 Oct. 2019

Accepted: 27 Oct. 2019

\begin{abstract}
Scientific initiation projects should stimulate and promote research in different areas of knowledge. Therefore, this study analyzed the projects of scientific initiation related to the area of environmental education in a private higher education institution, between 1998 and 2018. The study revealed a very small number of projects related to environmental education ( $0.23 \%)$. The majority (70\%) performed in the last 10 years; of the scientific initiation program category (SIP-50\%) and developed in courses in the Biological and Human areas (70\%). Considering the importance of Environmental Education based on sustainability, preservation, and conservation of the environment, for scientific, environmental, and citizen education of students, it is recommended actions that stimulate the execution of more projects in this area be developed.
\end{abstract}

Keywords: scientific contribution, higher education, scientific research

\section{INTRODUCTION}

In 1951 Brazil created the National Council for Scientific and Technological Development (CNPq), as a result of the need to institutionalize actions to encourage and foster research (Massi \& Queiroz, 2010).

As described by CNPq, there are several scientific initiation programs (CI) that serve as a theoretical and methodological support tool for the execution of projects that aim to contribute to the student's professional education (Bastos et al., 2010), enabling their involvement in the scientific research, with or without financial aid (CNPq, 2019).

The programs offered by $\mathrm{CNPq}$ for higher education students use the Scientific Initiation Scholarship Program (PIBIC), the Institutional Initiation Scholarship Program in Technological Development and Scientific Innovation (PIBITI), the Institutional Scientific Initiation Scholarship Program in Affirmative Actions (PIBIC-Af) and the Scientific Initiation and Master's Program (PICME) (CNPq, 2019).

In addition to these categories offered by $\mathrm{CNPq}$, Higher Education Institutions (HEIs) may offer other financial options, funded by HEIs. However, regardless of the type of CI, the central objective of the programs is to insert and fix the student in the course and the academy, develop scientific thinking, initiate research, generate scientific knowledge (CNPq, 2019), include a study routine, create a different curriculum structure and improve oral and written expression, critical reading and manual skills (Fava de Moraes \& Fava, 2000).

The research carried out by the IC addresses diverse topics and diverse areas, and an area of Environmental Education (EE), originated as a response to the demand generated by the environmental crisis, intensely studied by the national and international scientific community, has been gaining space in recent analyzes (Martins \& Schnetzler, 2018)

In fact, the most recent expansion in the demand for knowledge and information on environmental issues is highlighted, especially an EE. The EE involves actions that seek the maintenance of life and face social and environmental degradation and is regulated by Law No. 9,795 / 1999, which provides for Environmental Education and the National Policy for Environmental Education (NPEE). The NPEE defines an EE as a process where members and the community build social values, knowledge, skills, attitudes and competencies focused on environmental conservation (Brasil, 1999).

As such, research in the field of EE is important for sustainable development, which includes economic growth, environmental and social protection, which meets the needs of the present without compromising the ability to use upcoming 
Table 1. Program categories and Scientific Initiation (CI), funding agencies and student financial benefits

\begin{tabular}{lll}
\hline Category CI programs & Funding agencies & Financial benefits \\
\hline \multirow{2}{*}{ PIBIC: Scientific Initiation Scholarship Program } & CNPq/FA & $\begin{array}{l}\text { Monthly scholarship for 12 months to the CI } \\
\text { student. }\end{array}$ \\
\hline $\begin{array}{l}\text { PIBIT: Institutional Program of Initiation Scholarship in Technological CNPq } \\
\text { Development and Scientific Innovation }\end{array}$ & ICETI & $\begin{array}{l}\text { Monthly scholarship for 12 months to the CI } \\
\text { student }\end{array}$ \\
\hline \multirow{2}{*}{ PROBIC: Institutional Scientific Initiation Scholarship Program } & ICETI & $\begin{array}{l}\text { Monthly scholarship for 12 months to the CI } \\
\text { student }\end{array}$ \\
\hline PIC: Scientific Initiation Program & Don't have & Don't have \\
\hline
\end{tabular}

CNPq - National Council for Scientific and Technological Development; FA - Araucaria Foundation; FUNADESP - National Foundation for the Development of Private Higher Education; ICETI - Cesumar Institute of Science, Technology and Innovation

Source: elaborated by the authors

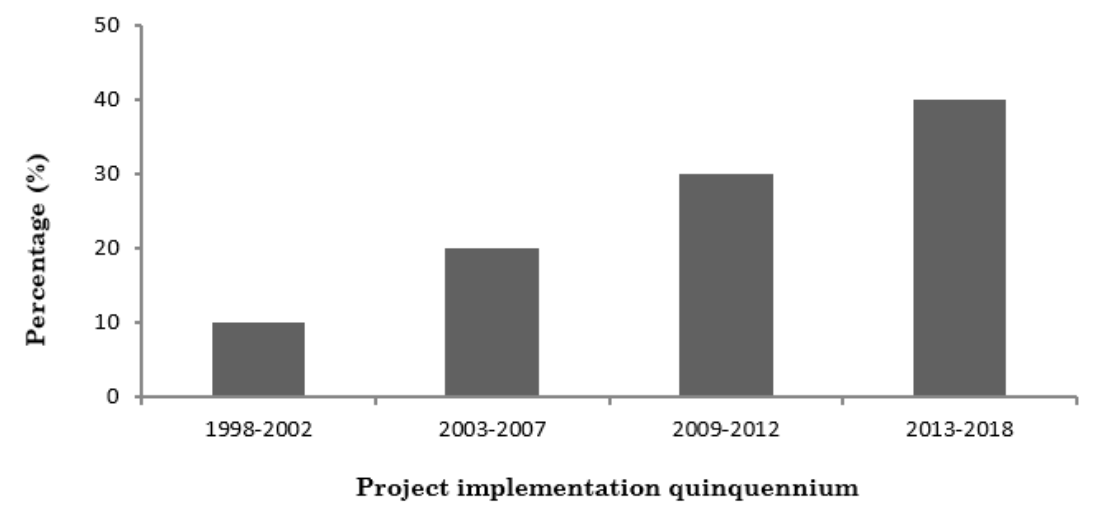

Figure 1. Percentage of undergraduate research projects in the field of Ambience Education, carried out in a private HEI between 1998 and 2018

Source: elaborated by the authors

usage opportunities as your needs (Brundtland, 1987). Concerned with securing sustainable development and supporting the Millennium Development Goals (MDGs), as the United Nations established in 2015 the Sustainable Development Goals (SDGs), which make up a global agenda of 17 objectives and 169 goals to be addressed reached by 2030 and involve broad and variable actions in pursuit of sustainable development that can end poverty, promote prosperity and be good for all, address climate change and protect the environment (UNESCO, 2019).

Several studies have analyzed the profile, production and outcome of CI in various fields of knowledge (Bastos et al., 2010; Goncalves et al., 2014; Zampieri et al., 2018), considering studies that associate CI with topics related, as is the case in the field of EE, are scarce in the scientific literature. Therefore, based on the importance and timeliness of EE, this study aimed to evaluate the evolution of scientific initiation projects related to the area of Environmental Education, during a historical series of 20 years, in a Brazilian private HEI.

\section{METHODOLOGY}

A cross-sectional quantitative cross-sectional study of the evolution of CI projects related to the Environmental Education area was carried out, using a historical series of 20 years, from 1998 to 2018 .

The data were made available by the Higher Institution Research Directorate located in southern Brazil and the data search was performed in March 2019 in the Research Directorate database following a research, analysis and selection protocol in the 4,317 projects registered since the institution's CI Program was implemented in 1998.

Total of 4.317 applicable projects, only 10 were selected and included in the research, and after that, data were collected from: (a) year of project execution; (b) CI program category (Table 1); (c) funding agency (Table 1); (d) Major areas of $\mathrm{CNPq}$ to which the project belongs and (e) project undergraduate course. The captured data were tabulated, organized in spreadsheets and calculated using descriptive statistics.

\section{RESULTS AND DISCUSSION}

This study revealed a small number of projects developed at HEI, since the implementation of the Scientific Initiation Program in 1998, focused on the area of Environmental Education, only $0.23 \%$ (10/4317). This small number of projects is critical since, due to the wide scope of the EE area, a larger number of projects were expected.

Regarding the historical evolution, the study allowed the identification of the number of scientific projects according to the five-year period, from 1998 to 2018 (Figure 1), showing an increasing behavior, showing that $70 \%$ (7/10). The projects were developed in the last 10 years.

Regarding the category of CI programs (Figure 2), it was observed that the majority (50\%) of the developed projects were of the PIC type, ie, without financial aid, followed by projects with institutional aid - PROBIC (40\%). The only PIBIC developed was aided by the funding agency - Fundação Araucária (PIBIC-FA) (10\%). 


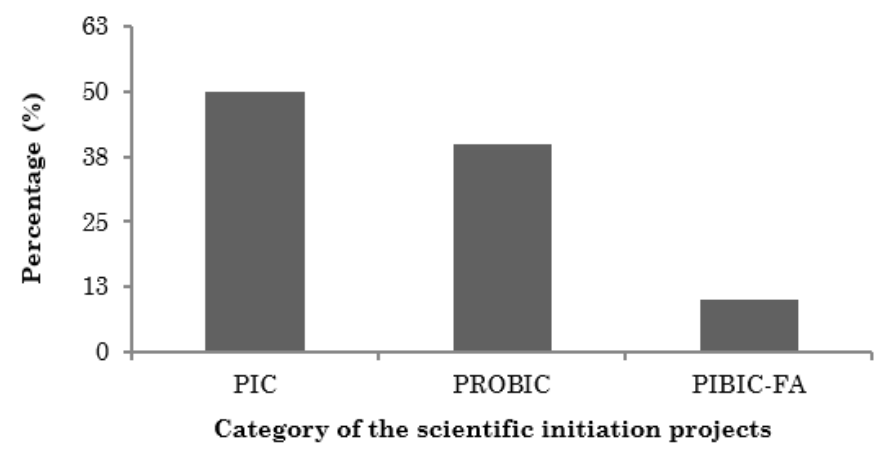

Figure 2. Percentage of scientific initiation projects in the area of Environmental Education, carried out in a private HEI between 1998 and 2018, according to the category

Source: elaborated by the authors

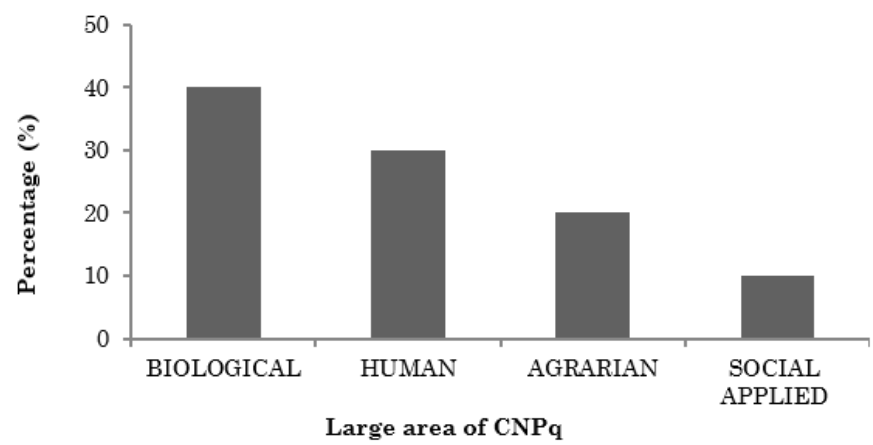

Figure 3. Percentage of scientific initiation projects in the area of Environmental Education, carried out in a private HEI, between 1998 and 2018, according to the major areas of $\mathrm{CNPq}$ Source: elaborated by the authors

Data on the distribution of projects according to major areas of knowledge, based on CNPq, showed that most (70\%) were developed by students from the Biological and Human areas (Figure 3). The classification of areas of knowledge seeks to provide educational institutions with a way to categorize and provide information related to research projects and human resources to management bodies (CAPES, 2019).

In order to obtain more information, the data were stratified according to the undergraduate courses involved with the development of projects and it was found that the undergraduate course in Biological Sciences stood out with the largest share of projects (40\%) (Figure 4).
The small number of scientific initiation projects in the field of EE observed in this study is worrying. Environmental education encompasses values, theories and practices that aim at maintaining life and building a better world, seeking to tackle social and environmental degradation through dialogic and participatory means. Due to its importance, Law No. 9.795, which provided for Environmental Education and which established the National Environmental Education Policy (NEEP) was created on April 27, 1999 (Brasil, 1999).

Law No. 9.795 defined environmental education as a process in which both the individual and the community produce social values, knowledge, skills, attitudes, and competencies aimed at the conservation of the environment, which are essential points for achieving a healthy and sustainable life. The Law emphasizes that EE must articulate all levels and modalities of the educational process and also points to the right to environmental education for all citizens, giving various sectors and segments of society the scope of their actions, among others. For them, the NEEP emphasizes that educational institutions must promote environmental education in an integrated manner with the educational programs they develop (Brasil, 1999), a fact not observed in this study.

The NEEP specifies, among the fundamental objectives of $\mathrm{EE}$, the development of an integrated understanding of the environment in its various relationships, involving ecological, psychological, legal, political, social, economic, scientific, cultural and ethical aspects and the guarantee of democratization. Environmental information and the stimulation and strengthening of a critical awareness about environmental and social issues (Brasil, 1999).

Therefore, to achieve these objectives, the NEEP must involve organs and entities that are part of the National Environment System (SISNAMA), public and private educational institutions, public agencies of the Union, the States, the Federal District and Municipalities, and nongovernmental organizations acting in environmental education and also emphasizes that the activities must interrelate and be developed in general education and school education (Brasil, 1999).

Studies on the impact of CI on the working lives of CI students show that these students are 2.2 times more likely to complete their master's degree and 1.5 times more likely to complete their doctorate degree, who complete their younger

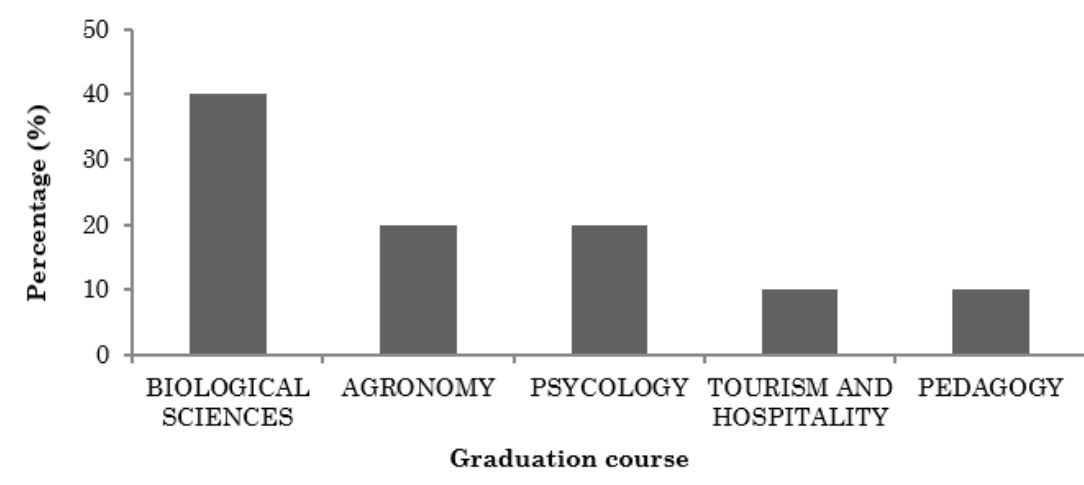

Figure 4. Percentage of scientific initiation projects in the area of Environmental Education, carried out in a private HEI, between 1998 and 2018, according to undergraduate courses

Source: elaborated by the authors 
undergraduate degree, have a higher pay $5 \%$ higher, and $56 \%$ have contact with foreign language and participate in scientific events (CGEE, 2017). Other benefits also include increased student involvement in their undergraduate degree, in academia, and the development of scientific knowledge and thinking (CNPq, 2019). The differentiated curriculum structure and oral, written and reading skills and the development of manual skills are also listed as benefits for CI students (Fava de Moraes \& Fava, 2000). CI experience contributes to the development of many skills and abilities.

However, it is considered that for CI programs to be successful in all their dimensions, it would be better to provide, besides the benefits to the students involved, a uniform coverage between the different areas of knowledge, a situation not found in this research, which allowed us to observe a large gap regarding the area of EE. In fact, Hugé et al. (2016) reported that higher education is a growing field of reflection and practice on sustainability, but its integration with academic research is still considered a challenge.

To overcome the challenges, it must be acknowledged that EE, as pointed out by Martins and Schnetzler (2018), is a recent social phenomenon, originated and enhanced by responses from the national and international scientific community to the demand generated by the environmental crisis and, in addition, In addition, CI projects in EE should have an interdisciplinary approach, seeking to solve social and environmental problems from the perspective of sustainable development.

\section{CONCLUSION}

The study on the historical evolution and the contribution of the undergraduate research projects of the evaluated HEI showed a seriously reduced number of projects in the area of Environmental Education, however, there was a growth in the number of projects from 2009. It was also found that most of the projects developed were of the PIC type and developed by the Biological Sciences course.

Given the results found and the importance of Environmental Education as a tool for sustainable development, it is suggested that institutional actions be promoted to stimulate the execution of more CI projects related to this area, aiming to guarantee students scientific, environmental and citizen education.

\section{REFERENCES}

Brasil (1999). Lei No 9.795, 27 April 1999. Política Nacional de Educação Ambiental. Retrieved on 24 September 2019 from http://www.mma.gov.br/port/conama/legiabre.cfm?codleg $\mathrm{i}=321$
Brundtland, G. H. (1987). Our common future: the world commission on environment and development. Oxford: Oxford University Press.

Centro de Gestão e Estudos Estratégicos - CGEE (2019). A Formação de novos quadros para CT\&I: avaliação do programa institucional de bolsas de iniciação. Brasília, DF. 2017. 175p. Retrieved on 24 September 2019 from https://www.cgee.org.br/documents/10195/734063/2373 PIBIC_Relat\%C3\%B3rio_complcom.pdf

Conselho Nacional de Desenvolvimento Científico e Tecnológico - CNPq (2019). Retrieved on 24 September 2019 from http://www.cnpq.br/web/guest/pibic/

Coordenação de Aperfeiçoamento de Pessoal de Nível Superior - CAPES (2019). Retrieved on 24 September 2019 from http://www.capes.gov.br/avaliacao/instrumentos-deapoio/tabela-de-areas-do-conhecimento-avaliacao

Fava de Moraes, F., \& Fava, M. (2000). A iniciação científica: algumas vantagens e alguns riscos. São Paulo em Perspectiva, 14(1), 73-77. https://doi.org/10.1590/S010288392000000100008

Goncalves, E., Santos, M. I. P., Maia, B. T., Brandão, R. C. S., Oliveira, E. A., \& Martelli Júnior, H. (2014). Produção científica dos pesquisadores da área de pediatria no CNPq. Revista Brasileira de Educação Médica, 38(3), 349-355. https://doi.org/10.1590/S0100-55022014000300009

Hugé, J., Block, T., Waas, T., Wright, T., \& Dahdouh-Guebas, F. (2016). How to walk the talk? Developing actions for sustainability in academic research. Journal of Cleaner Production, 137(2016), 83-92. https://doi.org/10.1016/ j.jclepro.2016.07.010

Martins, J. P. A., \& Schnetzler, R. P. (2018). Formação de professores em educação ambiental crítica centrada na investigação ação e na parceria colaborativa. Ciência \& Educação, 24(3), 581-598. https://doi.org/10.1590/1516731320180030004

Massi, L., \& Queiroz, S. L. (2010). Estudos sobre iniciação científica no Brasil: uma revisão. Cadernos de Pesquisa, 40(139), 173-197. https://doi.org/10.1590/S0100-15742010 000100009

United Nations Educational, Scientific and Cultural Organization- UNESCO - Agenda de Desenvolvimento Pós2015 e os Objetivos de Desenvolvimento Sustentável (2019). Retrieved on 24 September 2019 from http://www.unesco.org/new/pt/brasilia/post-2015development-agenda/

Zampieri, V. H., Santin, J. C., Sousa, K. M. C., Lopes, H. S. S., Sanches, S., Silva, H. N., Ishikawa, A. A., Almeida, A. P. F. Pontes, F. M., \& Cavalin, R. (2018). Contribuições da iniciação científica no aprendizado e desenvolvimento dos estudantes no ensino superior. Revista de Ciências Sociais do Norte de Mato Grosso, 7(1). 